\title{
Prevalence of the Third Head of the Lateral Pterygoid Muscle: A Magnetic Resonance Image Study
}

\author{
Prevalencia de la Tercera Cabeza del Músculo Pterigoideo Lateral: \\ Estudio con Imágenes de Resonancia Magnética
}

"Horácio Pompei Filho; **Antonio Sergio Guimarães \& ${ }^{* * *}$ Iván Claudio Suazo Galdames

POMPEI FILHO, H.; GUIMARÃES, A. S. \& SUAZO, G. I. C. Prevalence of the third head of the lateral pterygoid muscle a magnetic resonance image study. Int. J. Morphol., 27(4):1043-1046, 2009.

SUMMARY: The lateral pterygoid muscle (LPM) is important in the physiology and dysfunction of the temporomandibular joint (TMJ), which has described the presence of a third head in the lateral pterygoid muscle (THLPM). The purpose of this study was to evaluate the prevalence of THLPM and its relationship with the TMJ disc through magnetic resonance imaging (MRI). It was evaluated 178 MRI of the TMJ of healthy individuals, in images that presented THLPM, and these were defined and measured at the surface inserted into the disc. The prevalence of THLPM was $20.22 \%(\mathrm{n}=36)$. Insertion of THLPM was made entirely on the TMJ disc, the average area of insertion was 4.14mm (SD 1.35) in women and 4.67 (SD 2.68) in men, but these differences were not significant. We concluded that the LPM has a complex structure, and that a THLPM could contribute in the development of TMJ disc function alterations and anterior disc displacement.

KEY WORDS: Lateral pterygoid muscle; Temporomandibular joint; Articular disc; Temporomandibular dysfunction.

\section{INTRODUCTION}

The lateral pterygoid muscle (LPM) is a craneomandibular muscle derived from the first pharyngeal arch, and plays an important role in the mandibular movements and the dynamics of the temporomandibular joint. It is a short muscle, flattened shape of prismatic located in the infratemporal region. Its formation is classically described as a biceps muscle, in which its fibers originate from two muscle fascicles and are directed from the sphenoid to the neck of the mandibular head.

Superior fascicle or sphenoid: its fibers begin in the horizontal portion of the greater wing of sphenoid bone and extend up to the infratemporal crest and in the superior fourth in lateral side of the lateral wing of the pterygoid process. From this origin, the superior fascicle fiber projects obliquely to the inferolateral and posterior portions and inserts into the pterygoid fossa of the neck of the mandibular head (most of the fibers) and the anteromedial portion of the capsule and the temporomandibular joint disc. (Naohara, 1989; Bittar et al., 1994; Naidoo \& Juniper, 1997; Zhang et al., 1998;
Filho \& Alves, 2006 and Alves, 2008).

Inferior fascicule pterygoid: It originates through direct fiber from inferior three quarters of the lateral side of the lateral wing of the pterygoid process, including a small portion of the pyramidal process of the palatine bone and may project some fibers to the maxillary tuberosity. From its origins, the muscle fibers of the inferior fascicles are oriented superolaterally and posterior fascicles are inserted into the pterygoid fossa of the neck of the condyle.

This classic description has been discussed recently. Usui et al. (2008) have previously indicated that the margins between the two heads were difficult to distinguish. Desmons et al. (2007) had reported that the complex structure of the LPM resembles that of peniform muscles. On the other hand, Fujita et al. (2001), in an anatomic study, reported the presence of a third head at a superior location of the THLPM, identifiable due to a fascial sheath in 7 of the 20 bodies analyzed.

\footnotetext{
* Mestre em Odontologia, Centro de Pós-Graduação / CPO São Leopoldo Mandic, Campinas, Brasil.

* Instituto da Cabeça, Universidade Federal de São Paulo, Brazil.

*** Professor \& Head, Department of Anatomy, Universidad de Talca, Chile.
} 
Given the importance that LPM has in the physiology of the temporomandibular joint (TMJ) and its implication in the joint dysfunction, the purpose of this study was to evaluate using magnetic resonance image the presence of the third head of the lateral pterygoid muscle (THLPM) and their relationship with the TMJ disc.

\section{MATERIAL Y METHOD}

It was analysed 178 TMJs (103 adults, 20-45 years) using magnetic resonance image (MRI) T1, obtained in corrected sagittal plane, from Computerized Tomography Center of the Samaritano Hospital Sao Paulo - Brazil. This study was conducted with the informed consent of patients at the time of taking the images and the approval of the Ethics Committee of the Hospital.

The examinations were requested by different clinical service for various reasons, but those with a history of mandibular lock whether in opening or closing, disc adherence, trauma, or study in pre- and/or postoperative evaluation of the TMJ surgery were excluded.

The images were analyzed using the program MEVIS 2.9 , then the anatomical components of the articulations were identified, delimiting the heads of the lateral pterygoid muscle and the disc, and wherever a third head was found, it was defined and measured at the insertion disc surface (Fig. 1) The significance of the differences was analyzed by t-test for independent samples with $\mathrm{p}<0.05$.

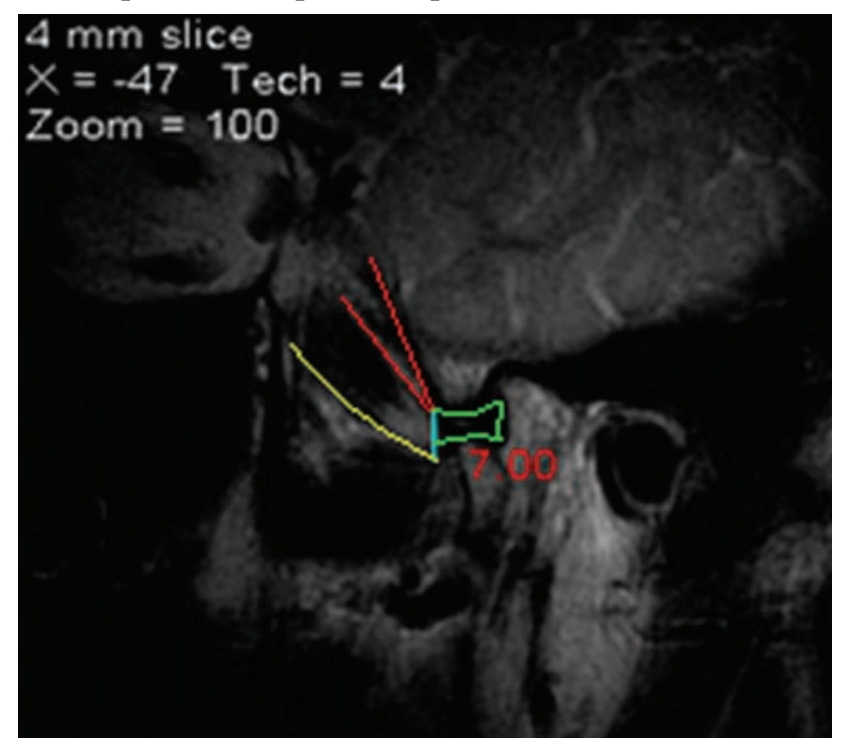

Fig. 1. MRI image of the TMJ, the superior and inferior margins of the third head of the lateral pterygoid muscle are bound with red. In yellow is observed in the inferior margin of the THLPM, with its insertion area into the disc in blue. The joint disc narrows in green.

\section{RESULTS}

Of the total number of images examined, 36 exhibite a third head in the lateral pterygoid muscle, which corresponded to $20.22 \%$ of the total sample.

Details of the distribution of presence of the third head of the LPM are found in Table I.

The THLPM insertion was made entirely on the TMJ disc surface. The average insertion area was $4.14 \mathrm{~mm}$ (SD 1.35 ) and 4.67 (SD 2.68) in women and men, respectively, and the differences were not significant.

Table I. Distribution by sex and side of the third head of the lateral pterygoid muscle, examined by MRI.

\begin{tabular}{llll}
\hline & Mens & Womans & Total \\
\hline Right & 6 & 14 & 20 \\
Left & 6 & 10 & 16 \\
Total & 12 & 24 & 36 \\
\hline
\end{tabular}

\section{DISCUSSION}

The presence of the THLPM is inadequately described in the literature. In this study, we found a prevalence of $20.22 \%$ of the presence of this variation on a sample of TMJ in asymptomatic individuals. In all the cases the insertion was made in the TMJ disc; this is significant because the orientation of the fibers suggests an important activity in the stabilization of the disc in relation to the articular tubercle of the temporal bone.

Moreover, the arrangement of the fibers, in the form of a fan and the difficulty in determining the boundaries between the heads seem to consider arguments in favor of the LPM as being a multipeniform muscle. This description could be based on the physiological observations, which indicate that the motor units of the LPM are activated at different phases of the joints movement, independent of the portion of the muscle to which they belong (Bhutada et al., 2008).

The THLPM's role in the anterior movement of the disc should also be evaluated. Tanaka et al. (2007) indicated that the increased activity of LPM is involved in the disc overtaking, so a THLPM fully inserted into the disc could be involved in the etiology of this alteration.

The THLPM is considered an anatomical variation 
despite the prevalence found in this study, which suggests that their presence may have a clinical significance. We concluded that the LPM has a complex structure, and that a
THLPM could participate in the development of alterations in disc function and in the presence of anterior disc displacement.

POMPEI FILHO, H.; GUIMARÃES, A. S. \& SUAZO, G. I. C. \&Estudio de prevalencia de la tercera cabeza del músculo pterigoideo lateral empleando imagenes de resonancia magnética. Int. J. Morphol., 27(4):1043-1046, 2009.

RESUMEN: El músculo pterigoideo lateral (MPL) tiene importancia en la fisiología y en la disfunción de la articulación temporomandibular (ATM), se ha descrito la presencia de una tercera cabeza en el músculo pterigoideo lateral (TCPL). El propósito de este estudio fue evaluar mediante resonancia nuclear magnética (RNM) la prevalencia de la TCPL y su relación con el disco de la ATM. Se evaluaron 178 RNM de ATM de individuos sanos. En las imágenes que presentaron TCPL éstos fueron delimitados y se midió la superficie inserta en el disco. La prevalencia de la TCPL fue del 20,22\% (n=36). La inserción de la TCPL se realizó completamente en el disco de la ATM, la media del área de inserción fue de 4,14mm (DS. 1,35) en mujeres y 4,67 (DS. 2,68) en hombres, estas diferencias no resultaron significativas. Concluimos que el MPL presenta una estructura compleja y que una TCPL podría participar en el desarrollo de alteraciones en la función discal y en la presencia de desplazamiento anterior del disco.

PALABRAS CLAVE: Músculo pterigoideo lateral; Articulación temporomandibular; Disco articular; Disfunción temporomandibular.

\section{REFERENCES}

Alves, N. Study about the development of the temporomandibular joint in the human fetuses. Int. J. Morphol., 26(2):309-12, 2008.

Bhutada, M. K.; Phanachet, I.; Whittle, T.; Peck, C. C. \& Murray, G. M. Regional properties of the superior head of human lateral pterygoid muscle. Eur. J. Oral Sci., 116(6):518-24, 2008.

Bittar, G. T.; Bibb, C. A. \& Pullinger, A. G. Histologic characteristics of the lateral pterygoid muscle insertion to the temporomandibular joint. J. Orofac. Pain, 8:243-9, 1994.

Desmons, S.; Graux, F.; Atassi, M.; Libersa, P. \& Dupas, P. H. The lateral pterygoid muscle, a heterogeneous unit implicated in temporomandibular disorder: A literature review. Cranio, 25:283-91, 2007.

Filho, L. A. \& Alves, N. Insertion of the superior head of the lateral pterigoid muscle in the human fetuses. Int. J. Morphol., 24(4):643-9, 2006.

Fujita, S.; Iizuka, T. \& Dauber, W. Variation of heads of lateral pterygoid muscle and morphology of articular disk of human temporomandibular joint: Anatomical and histological analysis. J. Oral Rehabil., 28(6):560$71,2001$.

Guimarães, A. S. \& Marie, S. K. N. Emprego das imagens por ressonância magnética em tempo real na avaliação da dinâmica da articulação temporomandibular. In: Cardoso, R. J. A. \& Machado, M. E. L. Odontologia: arte e conhecimento. São Paulo, Artes Médicas, 2003. pp.239-64.

Naidoo, L. C. \& Juniper, R. P. Morphometric analysis of the insertion of the upper head of the lateral pterygoid muscle. Oral Surg. Oral Med. Oral Pathol. Oral Radiol. Endod., 83:441-6, 1997.

Naohara, H. The macroscopic and microscopic study of the human lateral pterygoid muscle. Tsurumi Shigaku, 15:1-26, 1989.

Tanaka, E.; Hirose, M.; Inubushi, T.; Koolstra, J. H.; van Eijden, T. M.; Suekawa, Y.; Fujita, R.; Tanaka, M. \& Tanne, K. Effect of hyperactivity of the lateral pterygoid muscle on the temporomandibular joint disk. J. Biomech. Eng., 129(6):890-7, 2007.

Usui, A.; Akita, K. \& Yamaguchi, K. An anatomic study of the divisions of the lateral pterygoid muscle based on the findings of the origins and insertions. Surg. Radiol. Anat., 30(4):327-33, 2008.

Zhang, L.; Sun, L. \& Ma, X. A macroscopic and microscopic study of the relationship between the superior lateral pterygoid muscle and the disk of the temporomandibular joint. Zhonghua Kou Qiang Yi Xue Za Zhi, 33:267-9, 1998. 
POMPEI FILHO, H.; GUIMARÃES, A. S.; SUAZO, G. I. C. Prevalence of the third head of the lateral pterygoid muscle a magnetic resonance image study. Int. J. Morphol., 27(4):1043-1046, 2009.

Correspondence to:

Prof. Dr. Antonio Sergio Guimarães

Instituto da Cabeça

Universidade Federal de São Paulo

Rua Botucatu, 740

Vila Clementino

CEP 04023-900

Sao Paulo, SP

BRASIL

Email: sergio@asgatm.com

Received: 15-02-2009

Accepted: 22-09-2009 


\title{
Bilateral Presence of Axillary Arch Muscle Passing Through the Posterior Cord of the Brachial Plexus
}

\author{
Presencia Bilateral del Arco Muscular Axilar Pasando \\ por el Fascículo Posterior del Plexo Braquial
}

"Minnie Pillay \& **Suja Mary Jacob

PILLAY, M. \& JACOB, S. M. Bilateral presence of axillary arch muscle passing through the posterior cord of the brachial plexus. Int. J. Morphol., 27(4):1047-1050, 2009.

SUMMARY: The axillary arch can be described as an anomalous muscular slip of latissimus dorsi muscle. In this paper, a rare case of bilateral axillary arch is reported during routine dissection of the axillary region of a 57-year old male cadaver. On both sides, the axillary arch muscle took origin from latissimus dorsi and teres major, and passed upwards through the posterior cord of the brachial plexus, but posterior to the bulk of axillary neurovascular bundle. It then split into two slips: the medial slip was inserted into the root of the coracoid process, while the lateral slip which was intracapsular, was attached to the lesser tubercle, above the attachment of subscapularis. The presence of the muscle has important clinical implications, and the position, bilateral presence, penetration of the posterior cord, and multiple connective tissue attachments makes the case most unique. The anatomy, surgical implications, and embryology of the anomalous muscle are discussed in this paper.

KEY WORDS: Axillary arch muscle; Posterior cord of brachial plexus; Axillary anatomy.

\section{INTRODUCTION}

Anatomical variations of the axilla are of great relevance due to the increasing surgical importance of this region during axillary surgery for breast cancer, reconstruction procedures, and axillary bypass operations.

One of the variations reported has been the presence of a muscle extending from the latissimus dorsi muscle to the pectoralis major muscle called variously as Langer's axillary arch, axillopectoral muscle, pectodorsal muscle and arcus axillaris (Langer, 1846; Bonastre et al., 2002). The presence of this muscle has important clinical implications. The muscular arch first identified by Ramsay in 1795, and described in 1812 (Ramsay, 1812), was later confirmed by Langer (Langer). Different variations of the axillary arch muscle have been reported subsequently by many authors (Ucerler et al., 2005; Rizk \& Harbaugh, 2008; Inzunza et al., 2008). We report here a very unusual case of bilateral anomalous axillary arch muscle.

\section{CASE REPORT}

During the routine dissection of a 57 year-old male cadaver in the Department of Anatomy, School of Medicine, Amrita Institute of Medical Sciences, Kochi, Kerala, we came across a bilateral anomalous axillary arch muscle. On both sides, the muscle had a tendinous origin from teres major and latissimus dorsi, arched across the axilla deep to the pectoralis major passing deep to the bulk of the axillary neurovascular bundle. The muscle was then observed to pass through the posterior cord of the brachial plexus (Figs. 1 and 2). The axillary nerve lay posterior to the muscle, while the lower subscapular nerve was medial to the muscle. Part of the subscapular artery was posterior to the origin of the muscle from teres major, and the muscular branch to subscapularis passed posterior to the fleshy part of the axillary arch muscle. The muscle ended in a tendon, which split into 2 slips on both sides (Fig. 3, which shows the right side). The medial slip was found to be inserted into the scapula near the coracoid process, while the lateral slip passed deep

\footnotetext{
* Professor, Department of Anatomy, Amrita School of Medicine, Amrita Institute of Medical Sciences, Kochi, Kerala,India.

*** Postgraduate student in Anatomy, Department of Anatomy, Amrita School of Medicine, Amrita Institute of Medical Sciences, Kochi, Kerala, India.
} 